June 23, 1991

\title{
PERCEIVED RISK, TRUST, AND NUCLEAR WASTE: LESSONS FROM YUCCA MOUNTAIN
}

\author{
Paul Slovic, Mark Layman, and James H. Flynn
}

Prepared for Riley E. Dunlap, Michael E. Kraft, and Eugene A. Rosa, eds., Public Opinion and Nuclear Waste, Duke University Press. 
Perceived Risk, Trust, and Nuclear Waste:

Lessons from Yucca Mountain

By the year 2000, the United States will have a projected 40,000 metric tons of spent nuclear fuel stored and awaiting disposal at some 70 sites. By 2035, after all existing nuclear plants have completed 40 years of operation, there will be approximately 85,000 metric tons (Technical Review Board, 1991). The amount of spent fuel needing disposal will continue to grow with the relicensing of existing nuclear plants and the possible construction of new facilities. The U.S. Department of Energy (DOE) has been under intense pressure from Congress and the nuclear industry to dispose of this accumulating volume of high-level waste since the passage of the Nuclear Waste Policy Act in 1982 and its amendment in 1987, by which Yucca Mountain, Nevada was selected as the only candidate site for the nation's first nuclear waste repository. The lack of a suitable solution to the waste problem is widely viewed as an obstacle to further development of nuclear power and a threat to the continued operation of existing reactors, besides being a safety hazard in its own right.

Yet, at this time, the DOE program has been brought to a halt by overwhelming political opposition, fueled by perceptions of the public that the risks are immense (Flynn et al., 1990; Kasperson, 1990; Kunreuther, Desvousges, \& Slovic 1988; Nealey \& Herbert, 1983; and this volume). These perceptions stand in stark contrast to the prevailing view of the technical community, which believes that nuclear wastes can be disposed of safely, in deep underground isolation. Officials from DOE, the nuclear industry, and their technical experts are profoundly puzzled, frustrated, and disturbed by public and political opposition that many of them believe is based upon irrationality and ignorance (see Table 1).

[Table 1 about here] 
Perceived Risk, Trust, and Nuclear Waste Slovic, Layman, Flynn / Page 2

A number of important events during the past several years underscore the seriousness of this problem.

1. Official opposition by the State of Nevada has increased substantially. In June, 1989, the Nevada legislature passed Assembly Bill 222, making it unlawful for any person or governmental entity to store high-level radioactive waste in the State. The State Attorney General subsequently issued an opinion that the Yucca Mountain site had been effectively vetoed under a provision of the Nuclear Waste Policy Act. The Governor instructed state agencies to disregard DOE's applications for environmental permits necessary to investigate the site. The State and DOE initiated federal lawsuits over continuance of the program and issuance of the permits needed for on-site studies. In September, 1990, the 9th U.S. Circuit Court of Appeals ruled that the state had acted improperly and ordered Nevada officials to issue the permits. To date, however, no permits have been issued.

2. In November, 1989 , the DOE, admitting dissatisfaction with its earlier assessments of the Yucca Mountain site, announced that it would essentially start over with, "for the first time," an integrated, responsible plan. This plan would subject technical studies to close outside scrutiny to ensure that decisions about Yucca Mountain would be made "solely on the basis of solid scientific evidence" (Moore, 1989).

3. In July, 1990, the National Research Council's Board on Radioactive Waste Management issued a strong critique of the DOE program, charging that DOE's insistence on doing everything right the first time has misled the public by promising unattainable levels of safety under a rigid schedule that is "... unrealistic, given the inherent uncertainties of this 
unprecedented undertaking," and thus vulnerable to "'show stopping' problems and delays that could lead to a further deterioration of public and scientific trust" (National Research Council, 1990, p. 1). The Board recommended, instead, a more flexible approach, permitting design and engineering changes as new information becomes available during repository construction and operation.

Perceptions of risk from radiation, nuclear power, and nuclear waste play a pivotal role in this story and need to be thoroughly understood if we are to make any progress in resolving the current impasse. Although we already know a good deal about perceptions in this domain (Slovic, 1990), most of our knowledge comes from rather general questions (e.g., "How great is the risk of a nuclear waste repository compared with the risks of $\mathrm{X}, \mathrm{Y}$, and Z?"). With some notable exceptions (Erikson, 1990; Lifton, 1976; Weart, 1988), there have been few attempts to penetrate the surface veneer of nuclear fear and provide insight into the nature and pervasiveness of people's concerns, the origins of these concerns, the emotions that underlie them, their legitimacy, and their likely stability. Analysis of the intense concerns associated with a nuclear waste repository is also important, we believe, for understanding the role that perceived risk plays in the opposition to many other unwanted facilities such as chemical-waste landfills and incinerators.

ATTITUDE, PERCEPTION, AND OPINION SURVEYS

There have been a number of surveys conducted recently to assess public attitudes, perceptions, and opinions regarding the management of high-level radioactive wastes. We 
Perceived Risk, Trust, and Nuclear Waste Slovic, Layman, Flynn / Page 4

shall focus here on the results from a series of surveys we conducted in 1988 and 1989 (Flynn et al., 1990).

Details of these surveys are reported in Table 2. More than 3300 respondents were questioned by telephone with regard to their perceptions of the risks and benefits associated with a nuclear waste repository, their support or opposition for the DOE repository program, their trust in the ability of DOE to manage the program, and their views on a variety of other issues pertaining to radioactive-waste disposal. In addition to a national survey, data were collected from three other populations of special interest: residents of Nevada, the state selected as the site for the proposed national repository, and residents of Southern California and Phoenix, the two major sources of visitors to Nevada. The Phoenix survey was less extensive than the others and will be discussed in the next section. Respondents were selected by means of a random digit dialing procedure. When telephone contact was made with a household, the interviewer asked to speak to the person 18 years or older who had the most recent birthday (to ensure random selection of respondents within each household). Response rates were high $(72 \%-84 \%)$ in each of the surveys.

[Table 2 about here]

When asked to indicate the closest distance they would be willing to live from each of 10 facilities, the median distance from an underground nuclear waste repository was 200 miles in the national, Nevada, ${ }^{1}$ and Southern California surveys, twice the distance from the next most undesirable facility, a chemical-waste landfill, and three to eight times the distances from oil refineries, nuclear-power plants, and pesticide-manufacturing plants. In 
Perceived Risk, Trust, and Nuclear Waste Slovic, Layman, Flynn / Page 5

response to the statement "Highway and rail accidents will occur in transporting the wastes to the repository site," the percentage of respondents who agreed or strongly agreed was $77.4 \%$ in Nevada, $69.2 \%$ in California, and $71.6 \%$ nationally. Similar expectations of problems were expressed with regard to future earthquake or volcanic activity at the site, contamination of underground water supplies, and accidents while handling the material during burial operations.

When asked whether a state that does not produce high-level nuclear wastes should serve as a site for a nuclear waste repository, $67.9 \%$ of the Southern California and $76.0 \%$ of the national respondents answered "no" (the question was not asked in Nevada). A majority of those polled in the Southern California and National surveys judged a single national repository to be the least fair of five disposal options (including storage at each nuclear plant, in each state, and in each of several regions, and dual repositories in the East and West).

Strong distrust of the DOE was evident from the responses to questions such as "The U.S. Department of Energy can be trusted to provide prompt and full disclosure of any accidents or serious problems with their nuclear waste management programs." In Southern California, $67.5 \%$ either somewhat or strongly disagreed with this statement. The corresponding rate of disagreement in the National survey was $68.1 \%$.

Nevadans were asked whether or not they would vote in favor of a repository at Yucca Mountain; $69.4 \%$ said they would vote against it, compared to $14.4 \%$ who would vote for it. About $68 \%$ of the Nevadans surveyed said they agreed strongly with the statement 
Perceived Risk, Trust, and Nuclear Waste Slovic, Layman, Flynn / Page 6

"The State of Nevada should do all it can to stop the repository." Another 12.5\% agreed somewhat with this statement; only $16.0 \%$ disagreed. When asked whether or not they favored Assembly Bill 222 that was passed in 1989 making it illegal to dispose of high-level nuclear waste in Nevada, $74 \%$ were in favor and $18.4 \%$ opposed the bill. Finally, $73.6 \%$ of Nevadans said that the state should continue to do all it can to oppose the repository even if that means turning down benefits that may be offered by the federal government; $19.6 \%$ said the state should stop fighting and make a deal.

Follow-up surveys of Nevada residents in October, 1990 and March, 1991 suggest that opposition and distrust have continued to rise (Flynn, Mertz, \& Slovic, 1991). The percentage of Nevadans who would vote against a repository at Yucca Mountain increased from $69.4 \%$ to $80.2 \%$. In response to a request to indicate "how much you trust each of the following to do what is right with regard to a nuclear waste repository at Yucca Mountain," the Governor of Nevada topped the list of officials, agencies, and institutions. DOE, the Nuclear Regulatory Commission (NRC), and the U.S. Congress were the least trusted entities (see Figure 1). Strong increases in trust were evident for the President, the Governor of Nevada, and the Nevada State Legislature. ${ }^{2}$ In contrast, trust in DOE and NRC declined between 1989 and 1991.

[Figure 1 about here]

Measures of trust in DOE, perceived risk, and opposition to a repository at Yucca Mountain were highly interrelated. Table 3 illustrates the link between trust in DOE to "provide full and prompt disclosure of any accidents or serious problems with a repository 
Perceived Risk, Trust, and Nuclear Waste Slovic, Layman, Flynn / Page 7

program" and perception of risk from highway or rail accidents during the transportation of wastes to a repository site. Table 4 illustrates the trust vs. perceived risk relationship with a rating scale measure of trust in DOE to "do the right thing with regard to a nuclear waste repository." In both tables, those who distrust DOE are much more likely to agree that highway and rail accidents will occur than are those who trust DOE. Table 5 illustrates the relationship between trust in DOE to disclose problems and the respondent's response to the question "Would you vote for a repository at Yucca Mountain?" Among those who disagree that DOE can be trusted to disclose accidents or serious problems with a repository program, about $85-90 \%$ would vote against a repository at Yucca Mountain. The percentage of votes against a repository drops to $65.1 \%$ for those who somewhat agree that DOE can be trusted and falls further to $33.3 \%$ among the few who strongly agree that DOE can be trusted. Other questions assessing trust, perceived risk, and opposition to a repository produced relationships similar to those in Tables 3, 4, and 5 .

[Tables 3,4 , and 5 about here]

\section{IMAGERY AND PERCEPTION}

Prior to answering any of the attitude or opinion questions, respondents in the national, Southern California, and Nevada surveys, along with the 802 respondents in Phoenix, were asked to free associate to the concept of a nuclear waste repository.

The potential for word associations to reveal the mental content of a person's subjective experience was recognized by Plato and has a long history in psychology, going back to Galton (1880), Wundt (1883), and Freud (1924). More recently, Szalay and Deese 
(1978) have employed the method of continued associations to assess people's subjective representative systems for a wide range of concepts. This method requires the subject to make repeated associations to the same stimulus, for example,

war: soldier

war: fight

war: killing

war: etc.

Szalay and Deese argue that the method of continued associations is an efficient way to determine the contents and representational systems of human minds without requiring those contents to be expressed in the full discursive structure of language. In fact, we may reveal ourselves through associations in ways we might find difficult to do if we were required to spell out the full propositions behind these associations through answers to questions. Evidence provided by Szalay and Deese and others demonstrates that responses produced by the method of continued associations are not erratic and whimsical, but are stable and relate clearly and naturally to a person's experiences and preferences. They are organized and structured in much the same way as perceptions, beliefs, and attitudes.

A related view is provided by Fiske, Pratto, and Pavelchak (1983), who describe an image as a "cognitive representation, a conception, or an idea, potentially containing both concrete and abstract impressions; ... a mental picture, but not necessarily visual" (p. 42). Cognitive images are often accompanied by affect and such affect-laden images have been found to have important behavioral consequences. Prejudicial images give rise to 
Perceived Risk, Trust, and Nuclear Waste Slovic, Layman, Flynn / Page 9

discrimination (Hamilton, 1981). Images of politicians affect voting behavior (Campbell, et al., 1960). Images of nuclear war affect an individual's level of antinuclear political activity (Fiske, Pratto, \& Pavelchak, 1983). Images of cities and states determine decisions about places to vacation (Slovic, et al., in press) or attendance at conventions (Kunreuther \& Easterling, 1990).

The repository images were elicited using a version of the method of continued associations adapted for a telephone interview. The elicitation interview proceeded as follows:

My next question involves word association. For example, when I mention the word "baseball," you might think of the World Series, Reggie Jackson, summertime, or even hot dogs. Today I am interested in the first six thoughts or images that come to mind when you think of an underground nuclear waste repository. ${ }^{3}$ Think about an underground nuclear waste repository for a minute. When you think about this underground nuclear waste repository, what is the first thought or image that comes to mind?

What is the next thought or image you have when I say underground nuclear waste repository?

Your next thought or image?

This continued until six associations were produced or the respondent drew a blank. 
Perceived Risk, Trust, and Nuclear Waste Slovic, Layman, Flynn / Page 10

The 3,334 respondents in the four surveys produced a combined total of exactly 10,000 word-association images to the repository stimulus. The associations were examined and were classified according to their content to 13 general or superordinate categories, one of which was a miscellaneous category. All but one superordinate category contained subordinate categories--in one case there were 17 subordinate categories that were judged to fit the theme of the major category. All in all, there were 92 distinct categories. Many of these contained multiple associations, judged to have similar meanings. For example, the subcategory labeled Dangerous/Toxic, within the superordinate category labeled Negative Consequences, included the terms danger, dangerous, unsafe, disaster, hazardous, poisonous, and so on.

The 13 superordinate categories and their 92 subcategories contained 9439 wordassociation images (94.4\% of the total). Some 561 associations were left uncategorized $\left(5.6 \%\right.$ of the total) ${ }^{4}$

Table 6 presents the 13 superordinate categories in order of their combined frequencies across all four samples. The one exception to this ordering is the relatively large miscellaneous category, which is presented last. The subordinate categories are also shown, ordered by frequency within their superordinate category. Table 7 presents an ordering of the subordinate categories without regard for the superordinate structure.

[Tables 6 and 7 about here]

The most arresting and most important finding is the extreme negative quality of these images. The two dominant superordinate categories, Negative Consequences and Negative 
Perceived Risk, Trust, and Nuclear Waste

Slovic, Layman, Flynn / Page 11

Concepts accounted for more than $56 \%$ of the total number of images. The dominant subordinate category, Dangerous/Toxic, contained almost $17 \%$ of the total number of images. The five largest subordinate categories
Ia. Dangerous/Toxic
$16.83 \%$
Ib. Death/Sickness
$7.83 \%$
Ic. Environmental Damage
$6.92 \%$
IIa. Bad/Negative
$6.81 \%$
IIb. Scary
$4.01 \%$

were thoroughly negative in affective quality and accounted for more than $42 \%$ of the total number of images. The four most frequent single associations were dangerous $(n=539)$, danger $(n=378)$, death $(n=306)$, and pollution $(n=276)$.

Positive imagery was rare. Category XII, Positive, accounted for only $1 \%$ of the images. Other generally positive concepts, Necessary (Category IX), employment (Category $\mathrm{Xb}$ ), and money/income (Category $\mathrm{Xc}$ ) combined to total only $2.5 \%$ of the images. The response "safe" was given only 37 times $(0.37 \%)$.

Other noteworthy features of the combined data are:

There were 232 associations pertaining to war, annihilation, weapons, and things military (Categories IIe and VIIb).

There were 85 associations relating to the long duration of storage necessary for nuclear wastes or the transfer of risk and responsibilities to future generations (XIIIa). There were surprisingly few (38) transportation images (XIIIc). 
The famous NIMBY position (not in my backyard) was expressed in 273 images (Category IId).

Nuclear waste repositories are sometimes referred to derisively as "dumps." Although dump imagery was definitely present, it was infrequent (40 associations). Studies of risk perception have found that the risks of nuclear reactors and nuclear wastes have a dread quality (8). There were definite signs of this in the images. Although the word "dread" was never mentioned specifically, many of the responses categorized as scary (IIb) reflected this quality (e.g., fear, horror, apprehension, terror).

Lack of trust in DOE or other governmental agents is a common finding in studies of public perceptions of nuclear-waste management. Associations indicative of distrust appeared in Category IIj, Negative Toward Decision Makers and Process, and Categories IIl and VIi, dealing with mistakes). A number of images in the Bad/Negative category also seemed to reflect lack of trust (e.g. stupid, dumb, illogical).

Jones et al. (1984) have attempted to characterize the key dimensions of stigma. Two of their major defining characteristics of stigma are peril and negative aesthetic qualities (ugliness, repulsion). These qualities dominate the repository images. Peril is pervasive throughout Categories I and II and elsewhere and negative aesthetics form the bulk of the subordinate categories bad/negative (IIa) and Decay, Slime, Smell (IIh). 
Perceived Risk, Trust, and Nuclear Waste Slovic, Layman, Flynn / Page 13

The image frequencies were very similar from one survey to another. Demographic differences were also small. The negativity of repository images was remarkably consistent across men and women of different ages, incomes, education levels, and political persuasions.

After free-associating to the repository stimulus, each respondent rated the affective quality of his or her associations on a five-point scale ranging from extremely negative to extremely positive. These affective ratings were highly correlated with the respondent's attitudes and perceptions of risk. For example, Table 8 shows a strong relationship between a person's rating of the first image they produced and their response to the question "Would you vote for a repository at Yucca Mountain?" More than $90 \%$ of the persons whose first image was judged very negative voted against a repository at Yucca Mountain; more than half of the persons whose first image was judged positive voted in favor of the repository. A similarly strong relationship was found between affective ratings of images and a person's judgment of the likelihood of accidents or other problems at a repository. Negativity of the image rating was also strongly related to support for the State of Nevada's opposition to the repository program.

[Table 8 about here]

What was learned by asking more than 3300 people to associate freely to the concept of a nuclear waste repository? The most obvious answer is that people don't like nuclear waste. However, these images (as well as the responses to the attitude and opinion questions) demonstrate an aversion so strong that to call it "negative" or a "dislike" hardly 
Perceived Risk, Trust, and Nuclear Waste Slovic, Layman, Flynn / Page 14

does it justice. What these responses reveal are pervasive qualities of dread, revulsion, and anger; the raw materials of stigmatization and political opposition.

Because nuclear waste is a by-product of an impressive technology capable of producing massive amounts of energy without contributing to greenhouse gases, one might expect to find associations to energy and its benefits--electricity, light, heat, employment, health, progress, the good life--scattered among the images. Almost none were observed. Moreover, people were not asked to reflect on nuclear waste; instead, they were asked about a storage facility (Phoenix survey) or a repository (other surveys). One might expect, following the predominant view of experts in this field, to find a substantial number of repository images reflecting the qualities "necessary" and "safe" (see Table 1). Few images of this kind were observed.

It appears that the repository has acquired the imagery of nuclear waste, through some process of transference--guilt by association. The transference is so natural, so powerful, that one state official involved in nuclear safety, upon hearing of these imagery results, indignantly accused us of having biased our respondents by calling the facility a "nuclear waste repository."

Evidence that the quality of repository imagery has not heretofore been appreciated comes from exhortations by nuclear power proponents to please not use the term "dump" when referring to the repository, because of the obvious connotations or imagery this word conveys (Carter, 1987). Not only is dump or garbage imagery relatively infrequent in the 
observed responses, such images would appear rather benign in comparison to the more prevalent responses.

\section{HOW DID IT GET THIS WAY?}

Imagery and attitudes so negative and so impervious to influence from the assessments of technical experts must have very potent origins. Weart's scholarly analysis of images shows that nuclear fears are deeply rooted in our social and cultural consciousness. He argues persuasively that modern thinking about nuclear energy employs beliefs and symbols that have been associated for centuries with the concept of transmutation--the passage through destruction to rebirth. In the early decades of the 20 th century, transmutation images became centered on radioactivity, which was associated with

"uncanny rays that brought hideous death or miraculous new life; with mad scientists and their ambiguous monsters; with cosmic secrets of death and life; ... and with weapons great enough to destroy the world ..." (Weart, 1988, p. 421).

But this concept of transmutation has a duality that is hardly evident in the imagery we observed. Why has the destructive aspect predominated? The answer likely involves the bombing of Hiroshima and Nagasaki which linked the frightening images to reality. The sprouting of nuclear energy in the aftermath of the atomic bombing has led Smith (1988) to observe:

Nuclear energy was conceived in secrecy, born in war, and first revealed to the world in horror. No matter how much proponents try to separate the 
Perceived Risk, Trust, and Nuclear Waste Slovic, Layman, Flynn / Page 16

peaceful from the weapons atom, the connection is firmly embedded in the minds of the public. (p. 62)

Research supports Smith's assertions. A study by Slovic, Lichtenstein, and Fischhoff (1979) found that, even before the accident at Three Mile Island (TMI), people expected nuclear-reactor accidents to lead to disasters of immense proportions. When asked to describe the consequences of a "typical reactor accident," people's scenarios were found to resemble scenarios of the aftermath of nuclear war. Replication of these studies after the TMI event found even more extreme "images of disaster."

Fiske, Pratto, and Pavelchak (1983) studied public images of nuclear war and obtained results that were similar to our repository images. The dominant themes of nuclear war were physical destruction (long-term, short-term, and immediate), death, injury, weapons, politics, hell, oblivion, nothingness, pain, contamination, radiation, end of civilization, and genetic damage. Dominant emotional images included fear, terror, worry, and sadness, with anger, hate, helplessness, and peace mentioned somewhat less frequently.

The shared imagery of nuclear weapons, nuclear power, and nuclear waste may explain some of the surprising results that have come from surveys that have examined perceived risks for these various forms of nuclear hazards. A nuclear waste repository is judged to pose risks at least as great as a nuclear power plant or a nuclear weapons test site (Kunreuther, Desvousges, \& Slovic, 1988). If asked to indicate the closest distance a facility could be built from one's home before one would want to move to another place or actively protest, people are far more averse to living near a nuclear waste repository than any other 
kind of facility studied, including a nuclear power plant, a chemical-waste landfill, or a pesticide-manufacturing facility (Flynn et al., 1990).

Further insights into the special quality of nuclear fear are provided by Erikson (1990), who draws attention to the broad, emerging theme of toxicity, both radioactive and chemical, that characterizes a "whole new species of trouble" associated with modern technological disasters. Erikson describes the exceptionally dread quality of technological accidents that expose people to radiation and chemicals in ways that "contaminate rather than merely damage; ... pollute, befoul, and taint rather than just create wreckage; ... penetrate human tissue indirectly rather than wound the surface by assaults of a more straightforward kind" (p. 120). Unlike natural disasters, these accidents are unbounded. Unlike conventional disaster plots, they have no end. "Invisible contaminants remain a part of the surroundings--absorbed into the grain of the landscape, the tissues of the body and, worst of all, into the genetic material of the survivors. An 'all clear' is never sounded. The book of accounts is never closed" (p. 121).

Another strong determiner of public perceptions is the continuing story of decades of mishandling of wastes at the nation's military weapons facilities, operated by DOE (National Academy of Sciences, 1989). Leakage from these facilities has resulted in widespread contamination of the environment, projected to require more than $\$ 150$ billion for cleanup over the next 30 years. The recent revelation of unprecedented releases of radiation from the Hanford, Washington weapons plant in the 1940s and 1950s (Marshall, 1990) will certainly 
compound the negative imagery associated with a nuclear waste repository and further undermine public trust in government management of nuclear-waste disposal.

\section{A CRISIS OF CONFIDENCE}

Analysis of these survey data provides insight into the remarkably negative attitudes towards radioactive waste disposal facilities and the impassioned opposition to government efforts to site high-level and low-level waste repositories. The negativity of perceptions and emotions associated with a repository are remarkable in light of the confidence that most technical analysts and engineers have in their ability to dispose of radioactive materials safely. Even the report of the National Research Council (1990), though highly concerned about the difficulties of predicting the long-term performance of a repository, conceded that "These uncertainties do not necessarily mean that the risks are significant, nor that the public should reject efforts to site the repository" (p. 13).

Chauncey Starr (1985), pointing to the public's lack of concern about the risks from tigers in urban zoos, has argued that "acceptance of any risk is more dependent on public confidence in risk management than on the quantitative estimates of risk . . . " (p. 98). Public fears and opposition to nuclear-waste disposal plans can be seen as a "crisis of confidence," a profound breakdown of trust in the scientific, governmental, and industrial managers of nuclear technologies.

Viewing the nuclear-waste problem as one of distrust in risk management gives additional insights into its difficulty. Social psychological studies (Rothbart \& Park, 1986) have validated "folk wisdom" by demonstrating that trust is a quality that is quickly lost and 
slowly regained. ${ }^{6}$ A single act of embezzlement is enough to convince us that our accountant is untrustworthy. A subsequent opportunity to embezzle that is not taken does little to reduce the degree of distrust. Indeed, 100 subsequent honest actions would probably do little restore our trust in this individual.

In this light, the 1989 attempt by DOE to regain the confidence of the public, the Congress, and the nuclear industry by simply rearranging its organizational chart and promising to do a better job of management and science in the future (Moore, 1989) appears naive. Trust, once lost, cannot be so easily restored. Similarly naive is the aim professed by DOE officials and other nuclear-industry leaders to change public perception and gain support by letting people see firsthand the safety of nuclear-waste management. The nature of any low-probability, high-consequence threat is such that adverse events will demonstrate riskiness but demonstrations of safety (or negligible risk) will require a very long time, free of damaging incidents. The intense scrutiny given to nuclear power and nuclear-waste issues by the news media (Mazur, 1990) insures that a stream of problems, occurring all over the world, will be brought to the public's attention, continually eroding trust.

\section{WHERE NEXT FOR NUCLEAR-WASTE DISPOSAL?}

Although everyone appreciates the sophisticated engineering required to store nuclear wastes safely, the political requirements necessary to design and implement a repository have not similarly been appreciated. As a result, notes Jacob (1990):

"While vast resources have been expended on developing complex and sophisticated technologies, the equally sophisticated political processes and 
institutions required to develop a credible and legitimate strategy for nuclear waste management have not been developed" (p. 164).

In the absence of a trustworthy process for siting, developing, and operating a nuclear waste repository, the prospects for a short-term solution to the disposal problem seem remote. The report of the National Research Council (1990) is quite sensitive to issues of risk perception and trust, but makes the strong assumption that trust can be restored by a process that openly recognizes the limits of technical understanding and does not aim to "get it right the first time." It seems likely that such open admission of uncertainty and refusal to guarantee safety might well have opposite effects from those intended--increased concern and further deterioration of trust. Moreover, the NRC statement also assumes that DOE will continue to manage the nuclear-waste program, thus failing to come to grips with the difficulties that DOE will face in restoring its tainted image.

The lack of a trustworthy process for siting, developing, and operating a nuclear waste repository has drawn a number of other comments and recommendations besides those of the National Research Council. Weinberg (1989) drew an analogy between fear of witches during the 15 th through 17 th centuries and today's fear of harm from radiation. He hypothesized that "rad-waste phobia" may dissipate if the intelligentsia (read environmentalists) say that such fears are unfounded, much as eventually happened with fears of witches. Carter (1987) argued that "Trust will be gained by building a record of sure, competent, open performance that gets good marks from independent technical peer reviewers and that shows decent respect for the public's sensibilities and common sense" (p. 
416). He also recommended that the National Academy of Sciences undertake a study to determine how an independent and credible process of peer review can be established to increase public trust in repository siting and development and to determine how state and local governments can best be given a voice in siting investigations and in oversight of actual repository operations. Others have called for more radical changes such as creating new organizations and developing procedures to ensure that state, local, and tribal governments have a strong voice in siting decisions and oversight of actual repository operations (e.g., Advisory Panel, 1984; Bella, Mosher, \& Calvo, 1988; Bord, 1987; Creighton, 1990; Jacob, 1990). In this spirit, an official of the Canadian government has argued for making repository siting in that country voluntary by requiring public consent as an absolute prerequisite for confirming any decision (Frech, 1991).

Whatever steps are taken, it is unlikely that the current "crisis in confidence" will be ended quickly or easily. We must settle in for a long effort to restore the public trust. Krauskopf (1990) has noted that postponing the repository to an indefinite future can be defended on a variety of technical grounds and points out that the choice between repository construction or postponement ultimately rests upon the shoulders of the public and their elected representatives. The problems of perception and trust described above imply that postponement of a permanent repository may be the only politically viable option in the foreseeable future.

In an address to the National Association of Regulatory Utility Commissioners in November, 1990, Joseph Rhodes, Jr., himself a commissioner from Pennsylvania, pointed 
out the implications of the polls indicating that most Nevadans oppose the siting of a repository anywhere in Nevada and want state leaders to oppose such siting with any means available (Rhodes, 1990). "I can't imagine," said Rhodes, "that there will ever be a usable Yucca Mountain Repository if the people of Nevada don't want it . . . There are just too many ways to delay the program ... " (p. 6).

What are the options in the light of dedicated public opposition to a permanent underground repository? Rhodes lists and rejects several:

Continuing on the present path in an attempt to site a permanent repository (which Rhodes refers to as the modern equivalent of "pyramids underground") is a costly and doomed effort.

Permanent on-site storage is unsafe.

Deploying a monitored retrievable storage (MRS) program is also politically unacceptable. Without a viable program to develop a permanent repository, the MRS would be seen, in effect, as the permanent site.

Reprocessing the spent nuclear fuel is also politically unacceptable because of concerns over nuclear-weapons proliferation. Moreover, reprocessing reduces but does not eliminate high-level wastes and the record of managing reprocessing residues at Hanford and other military sites is hardly encouraging.

Rhodes concludes that the only viable option is to delay the siting of a permanent repository for several decades and store the wastes on site in the interim -- employing dry- 
cask storage that has been certified by NRC as being as safe as geological storage for 100 or more years (Nuclear Regulatory Commission, 1990). Should this course of action be followed, technical knowledge will undoubtedly advance greatly during this interim period. Perceptions of risk and trust in government and industry may change greatly, too, if the problem of establishing and maintaining trust is taken seriously.

\section{BEYOND YUCCA MOUNTAIN}

The story of Yucca Mountain has implications for environmental decision making that transcend the conflicts and concerns surrounding the disposal of radioactive wastes. People's perceptions of chemicals are almost as negative as their perceptions of radioactivity. Any major facility that produces, uses, transports, or disposes of chemicals will face similar problems originating from perceptions of risk that bear little resemblance to the risk assessments of technical experts. No one is happy about the current state of affairs. Industrialists, scientists, politicians, and the public are united only in their anger and frustration about the ways that environmental risks are currently managed.

Restoration and preservation of trust in risk management needs to be given top priority. A solution to the problem of trust is not immediately apparent. The problem is not due to public ignorance or irrationality but is deeply rooted in the adversarial nature of our social, institutional, legal, and political systems of risk management. Public relations won't create trust. Aggressive and competent government regulation, coupled with increased public involvement, oversight, and local control over decision making might. 


\section{NOTES}

1. The Nevada results reported in this section are based upon the 500 respondents in the statewide survey.

2. The 1991 survey was conducted in the days following the conclusion of the Gulf War when President Bush's approval ratings had reached unprecedented levels.

3. Respondents in the Phoenix survey were asked to associate to the term "underground nuclear waste storage facility."

4. A complete listing of all 10,000 images, including those that were not categorized, is available from the authors.

5. The fact that the earliest technical risk assessments for nuclear power plants portrayed "worst-case scenarios" of tens of thousands of deaths and devastation over geographic areas the size of Pennsylvania likely contributed to such extreme images (see Ford, 1977). These early projections received enormous publicity, as in the movie The China Syndrome.

6. Abraham Lincoln, in a letter to Alexander McClure, observed: "If you once forfeit the confidence of your fellow citizens, you can never regain their respect and esteem."

7. Rhodes' assertion echoes an earlier statement made by a former DOE official, John O'Leary, in an interview with Luther Carter:

"When you think of all the things a determined state can do, it's no contest," O'Leary told me, citing by way of example the regulatory authority a state has with respect to its lands, highways, employment codes and the like. The federal courts, he added, would strike down each of the state's blocking actions, but meanwhile years would roll by and in a practical sense DOE's cause would be lost (Carter, 1987, p. 185). 
Perceived Risk, Trust, and Nuclear Waste

Slovic, Layman, Flynn / Page 25

\section{REFERENCES}

Advisory Panel on Alternative Means of Financing and Managing Radioactive Waste Facilities. 1984. Managing Nuclear Waste: A Better Idea. Report to the U.S. Secretary of Energy, Washington, D.C.

Bella, David A., Charles D. Mosher, and Steven N. Calvo. 1988. "Technocracy and Trust: Nuclear Waste Controversy." Journal of Professional Issues in Engineering, 114, 27-39.

Bord, Richard J. 1987. "Judgments of Policies Designed to Elicit Local Cooperation on LLRW Disposal Siting: Comparing the Public and Decision Makers." Nuclear and Chemical Waste Management, 7, 99-105.

Campbell, Angus, Philip E. Converse, W. E. Miller, and D. E. Stokes. 1960. The American Voter. New York: Wiley.

Carter, Luther J. 1987. Nuclear Imperatives and Public Trust: Dealing with Radioactive Waste. Washington, D.C.: Resources for the Future, Inc.

Cohen, Bernard L. 1983. Before It's Too Late: A Scientist's Case for Nuclear Energy. New York: Plenum.

Creighton, James. 1990. "Siting Means Safety First." Forum for Applied Research and Public Policy, 5(2): 97-98.

Erikson, Kai. 1990. "Toxic Reckoning: Business Faces a New Kind of Fear." Harvard Business Review Jan.-Feb.: 118-126.

Fiske, Susan, T., Felicia Pratto, and Mark A. Pavelchak. 1983. "Citizen's Images of Nuclear War: Contents and Consequences." Journal of Social Issues 39, 41-65.

Flynn, James, Paul Slovic, C. K. Mertz, and Jim Toma. 1990. Evaluations of Yucca Mountain. Report 90-4. Eugene, OR: Decision Research.

Flynn, James, C.K. Mertz, and Paul Slovic. 1991. The 1991 Nevada State Telephone Survey: Key Findings. Report 91-2. Eugene, OR: Decision Research.

Ford, Daniel F. 1977. The History of Federal Nuclear Safety Assessment: From WASH 740 Through the Reactor Safety Study. Cambridge, Massachusetts: Union of Concerned Scientists. 
Frech, Egon R. 1991. "How Can We Deal with NIMBY in Nuclear Waste Management?" Paper presented at the International High-Level Radioactive Waste Management Conference, May, 1991, Las Vegas, Nevada.

Freud, Sigmund. 1924. Collected Papers. London: Hogarth.

Galton, Francis. 1880. "Psychometric Experiments." Brain 2: 149-162.

Hamilton, David L. 1981. Cognitive Processes in Stereotyping and Intergroup Behavior. Hillsdale, New Jersey: Erlbaum.

Jacob, Gerald. 1990. Site Unseen: The Politics of Siting a Nuclear Waste Repository. Pittsburgh, PA: University of Pittsburgh Press.

Jones, Edward, Amerigo Farina, Albert Hastorf, Hazel Markus, Dale Miller, and Robert Scott. 1984. Social Stigma: The Psychology of Marked Relationships. New York: W. H. Freeman.

Kasperson, Roger. 1990. "Social Realities in High-Level Radioactive Waste Management and Their Policy Implications." In Proceedings of the International High-Level Radioactive Waste Management Conference, April, 1990, Las Vegas, Nevada.

Krauskopf, Konrad. 1990. "Disposal of High-Level Nuclear Waste: Is it Possible?" Science 249: 1231-1232 (1990).

Kunreuther, Howard, William H. Desvousges, and Paul Slovic. 1988. "Nevada's Predicament: Public Perceptions of Risk from the Proposed Nuclear Waste Repository. Environment 30, no. 8: 16-20, 30-33.

Kunreuther, Howard, and Douglas Easterling. 1990. Imagery and Convention Decision Making. Technical Report, Center for Risk and Decision Sciences, The Wharton School, University of Pennsylvania.

Lifton, Robert. 1967. Death in Life. New York: Basic Books.

Marshall, Eliot. 1990. "Hanford Releases Released." Science 249: 474.

Mazur, A. 1990. "Nuclear Power, Chemical Hazards, and the Quantity of Reporting." Minerva 28, 294-323.

Moore, W. Henson. 1989. Remarks before the 1989 Nuclear Energy Forum, San Francisco, November 28. 
National Academy of Sciences. 1989. The Nuclear Weapons Complex: Management for Health, Safety, and the Environment. Washington, D.C.: National Academy Press.

National Research Council. 1990. Rethinking High-Level Radioactive Waste Disposal. Washington, DC: National Academy Press.

Nealey, Stanley and John A. Hebert. 1983. "Public Attitudes Towards Radioactive Waste." In Charles A. Walker, Leroy C. Gould, and Edward J. Woodhouse, eds., Too Hot to Handle: Social and Policy Issues in the Management of Radioactive Wastes. New York: Yale University Press.

Nuclear Regulatory Commission. 1990. "Storage of Spent Fuel in NRC-Approved Storage Casks at Power Reactor Sites." Federal Register 55, no. 138: 29181-29195.

Rhodes, Joseph Jr. 1990. "Nuclear Power: Waste Disposal: New Reactor Technology." Address to the 102nd Annual Convention of the National Association of Regulatory Utility Commissioners, Orlando, Florida.

Rothbart, Myron, and Bernadette Park. 1986. "On the Confirmability and Disconfirmability of Trait Concepts." Journal of Personality and Social Psychology 50: 131-142.

Slovic, Paul. 1990. "Perception of Radiation Risks." In Radiation Protection Today--The NCRP at Sixty Years: Proceedings of the Twenty-fifth Annual Meeting of the National Council on Radiation Protection and Measurements. vol. 11.

Slovic, Paul, Mark Layman, Nancy Kraus, James Chalmers, Gail Gesell, and James H. Flynn. In press. "Perceived Risk, Stigma, and Potential Economic Impacts of a High-Level Nuclear Waste Repository in Nevada." Risk Analysis.

Slovic, Paul, Sarah Lichtenstein, and Baruch Fischhoff. 1979. "Images of Disaster: Perception and Acceptance of Risks from Nuclear Power." In Goodman and Rowe, eds., Energy Risk Management.

Smith, Kirk R. 1988. "Perception of Risks Associated With Nuclear Power." Energy Environment Monitor 4(1): 61-70.

Starr, Chauncey. 1985. "Risk Management, Assessment, and Acceptability." Risk Analysis 5: $97-102$.

Szalay, Lorand and James Deese. 1978. Subjective Meaning and Culture: An Assessment through Word Associations. Hillsdale, New Jersey: Erlbaum. 
Perceived Risk, Trust, and Nuclear Waste Slovic, Layman, Flynn / Page 28

Technical Review Board. 1991. Third Report to the U.S. Secretary of Energy. Nuclear Waste Technical Review Board, Arlington, VA.

Weart, Spencer. 1988. Nuclear Fear: A History of Images. Cambridge: Harvard University Press.

Weinberg, Alvin M. 1989. "Public Perceptions of Hazardous Technologies and Democratic Political Institutions." Paper presented at Waste Management '89, Tucson, Arizona.

Wundt, Wilhelm. 1883. "Uber Psychologische Methoden." Philosophische Studien 1, 1-38. 
Table 1

SOME VIEWPOINTS OF EXPERTS REGARDING PUBLIC PERCEPTIONS
OF THE RISKS FROM NUCLEAR-WASTE DISPOSAL

"Several years ago . . . I talked with Sir John Hill, . . . chairman of the United Kingdom's Atomic Energy Authority. 'I've never come across any industry where the public perception of the problems is so totally different from the problems as seen by those of us in the industry . . . ,' Hill told me. In Hill's view, the problem of radioactive waste disposal was, in a technical sense, comparatively easy" (Carter, 1987, p. 9).

"Nuclear wastes can be sequestered with essentially no chance of any member of the public receiving a non-stochastic dose of radiation. . . . Why is the public's perception of the nuclear waste issue at such odds with the experts' perception?" (Weinberg, 1989, pp 1-2).

"The fourth major reason for public misunderstanding of nuclear power is a grossly unjustified fear of the hazards from radioactive waste.... Often called an 'unsolved problem,' many consider it to be the Achilles' heel of nuclear power. Seven states now have laws prohibiting construction of nuclear power plants until the waste disposal issue is settled. On the other hand there is general agreement among those scientists involved with waste management that radioactive waste disposal is a rather trivial technical problem" (Cohen, 1983, p. 119).

"It is possible to estimate the risk [of a high-level nuclear waste repository] if the material is buried as planned. It turns out it is ridiculously low . . . The risk is as negligible as it is possible to imagine, yet the clamor about the subject has paralyzed the decision-making authorities, and there is still no consensus solution. It is embarrassingly easy to solve the technical problems, yet impossible to solve the political ones" (Lewis, 1990, p. 245-246). 
Perceived Risk, Trust, and Nuclear Waste

Slovic, Layman, Flynn / Page 30

Table 2

SURVEY DETAILS

\begin{tabular}{l|c|c|c}
\hline \hline Survey and Location & Dates & $\begin{array}{c}\text { Sample } \\
\text { Size }\end{array}$ & $\begin{array}{c}\text { Response } \\
\text { Rate (\%) }\end{array}$ \\
\hline & $4 / 13-6 / 8 / 88$ & 802 & 72 \\
Phoenix & $10 / 21-12 / 7 / 89$ & 825 & 77 \\
National & $12 / 6 / 89-1 / 1 / 90$ & 801 & 77 \\
Southern California & $9 / 25-10 / 15 / 89$ & 500 & 74 \\
NEVADA & $9 / 25-10 / 15 / 89$ & 204 & 74 \\
Statewide & $9 / 25-10 / 15 / 89$ & 101 & 84 \\
Nye County & $9 / 25-10 / 15 / 89$ & 101 & 77 \\
Lincoln County & & & \\
Esmeralda County & $9 / 25-10 / 15 / 89$ & 906 & 77 \\
& & & \\
Nevada Total & & & \\
& & & \\
\hline
\end{tabular}


Perceived Risk, Trust, and Nuclear Waste Slovic, Layman, Flynn / Page 31

Table 3

RELATIONShIP BETWEen TRUST IN DOE AND PERCEIVED RISK OF TRANSPORT ACCIDENTS

\begin{tabular}{ccccccc}
\hline \hline & \multicolumn{5}{c}{ Highway and Rail Accidents Will Occur } \\
\hline $\begin{array}{c}\text { DOE Can Be } \\
\text { Trusted }\end{array}$ & $\begin{array}{c}\text { Strongly } \\
\text { Disagree }\end{array}$ & $\begin{array}{c}\text { Somewhat } \\
\text { Disagree }\end{array}$ & Neutral & $\begin{array}{c}\text { Somewhat } \\
\text { Agree }\end{array}$ & $\begin{array}{c}\text { Strongly } \\
\text { Agree }\end{array}$ & N \\
\hline Strongly Disagree & 3.4 & 6.0 & 2.2 & 34.5 & 53.9 & 230 \\
Somewhat Disagree & 5.7 & 13.6 & 5.0 & 51.4 & 24.3 & 140 \\
Neutral & 14.3 & 28.6 & 14.3 & 28.6 & 14.3 & 7 \\
Somewhat Agree & 2.6 & 22.1 & 7.8 & 49.4 & 18.2 & 77 \\
Strongly Agree & 25.0 & 25.0 & 10.7 & 14.3 & 25.0 & 28 \\
\hline
\end{tabular}

$\chi^{2}=97.1 ; \mathrm{df}=.16 ; \mathrm{p}<.001$

Note: Cell entries are row percentages based upon data from the Nevada Survey.

a The Department of Energy can be trusted to provide full and prompt disclosure of any accidents or serious problems with a repository program.

b Highway and rail accidents will occur in transporting the wastes to the repository site. 
Perceived Risk, Trust, and Nuclear Waste Slovic, Layman, Flynn / Page 32

Table 4

RElationship BetweEn TRUST IN DOE AND PERCEIVED RISK of Transport ACcIDENTS

\begin{tabular}{|c|c|c|c|c|c|c|}
\hline \multirow[b]{2}{*}{ Trust Rating ${ }^{\mathbf{a}}$} & \multicolumn{6}{|c|}{ Highway and Rail Accidents Will Occur ${ }^{b}$} \\
\hline & $\begin{array}{l}\text { Strongly } \\
\text { Disagree }\end{array}$ & $\begin{array}{c}\text { Somewhat } \\
\text { Disagree }\end{array}$ & Neutral & $\begin{array}{c}\text { Somewhat } \\
\text { Agree }\end{array}$ & $\begin{array}{c}\text { Strongly } \\
\text { Agree }\end{array}$ & $\mathbf{N}$ \\
\hline 0 & 5.7 & 5.7 & 1.4 & 31.4 & 55.7 & 70 \\
\hline $1-4$ & 3.7 & 13.2 & 3.7 & 37.5 & 41.9 & 136 \\
\hline 5 & 5.1 & 9.3 & 6.8 & 44.9 & 33.9 & 118 \\
\hline $6-9$ & 5.3 & 13.0 & 3.8 & 50.4 & 27.5 & 131 \\
\hline 10 & 17.2 & 24.1 & 10.3 & 17.2 & 31.0 & 29 \\
\hline
\end{tabular}

$\chi^{2}=40.7 ; \mathrm{df}=.16 ; \mathrm{p}<.001$

Note: Cell entries are row percentages based upon data from the Nevada Survey.

a Based upon rating trust in DOE to do what is right with regard to a nuclear waste repository ( 0 = no trust; $10=$ complete trust).

b Highway and rail accidents will occur in transporting the wastes to the repository site. 
Perceived Risk, Trust, and Nuclear Waste

Slovic, Layman, Flynn / Page 33

\section{Table 5}

RELATIONSHIP BETWEEN TRUST IN DOE AND RESPONSE TO THE QUESTION "WOULD YOU VOTE FOR A REPOSITORY AT YUCCA MOUNTAIN?"

\begin{tabular}{cccccc}
\hline \hline \multicolumn{2}{c}{ DOE Can Be Trusted to Disclose Any Problems } \\
\hline Yucca Mountain Vote & $\begin{array}{c}\text { Strongly } \\
\text { Disagree }\end{array}$ & $\begin{array}{c}\text { Somewhat } \\
\text { Disagree }\end{array}$ & Neutral & $\begin{array}{c}\text { Somewhat } \\
\text { Agree }\end{array}$ & $\begin{array}{c}\text { Strongly } \\
\text { Agree }\end{array}$ \\
\hline Yes & 8.3 & 14.4 & 33.3 & 34.9 & 66.7 \\
No & 91.7 & 85.6 & 66.7 & 65.1 & 33.3 \\
N & 204 & 118 & 6 & 63 & 21 \\
\hline
\end{tabular}

$\chi^{2}=62.2 ; \mathrm{df}=.4 ; \mathrm{p}<.001$

Note: Cell entries are column percentages. Responses are based upon the survey of Nevada residents. 
Table 6

IMAGES OF A NUCLEAR WASTE REPOSITORY:

TOTALS FOR FOUR SURVEYS BY SUPERORDINATE AND SUBORDINATE CATEgorIES

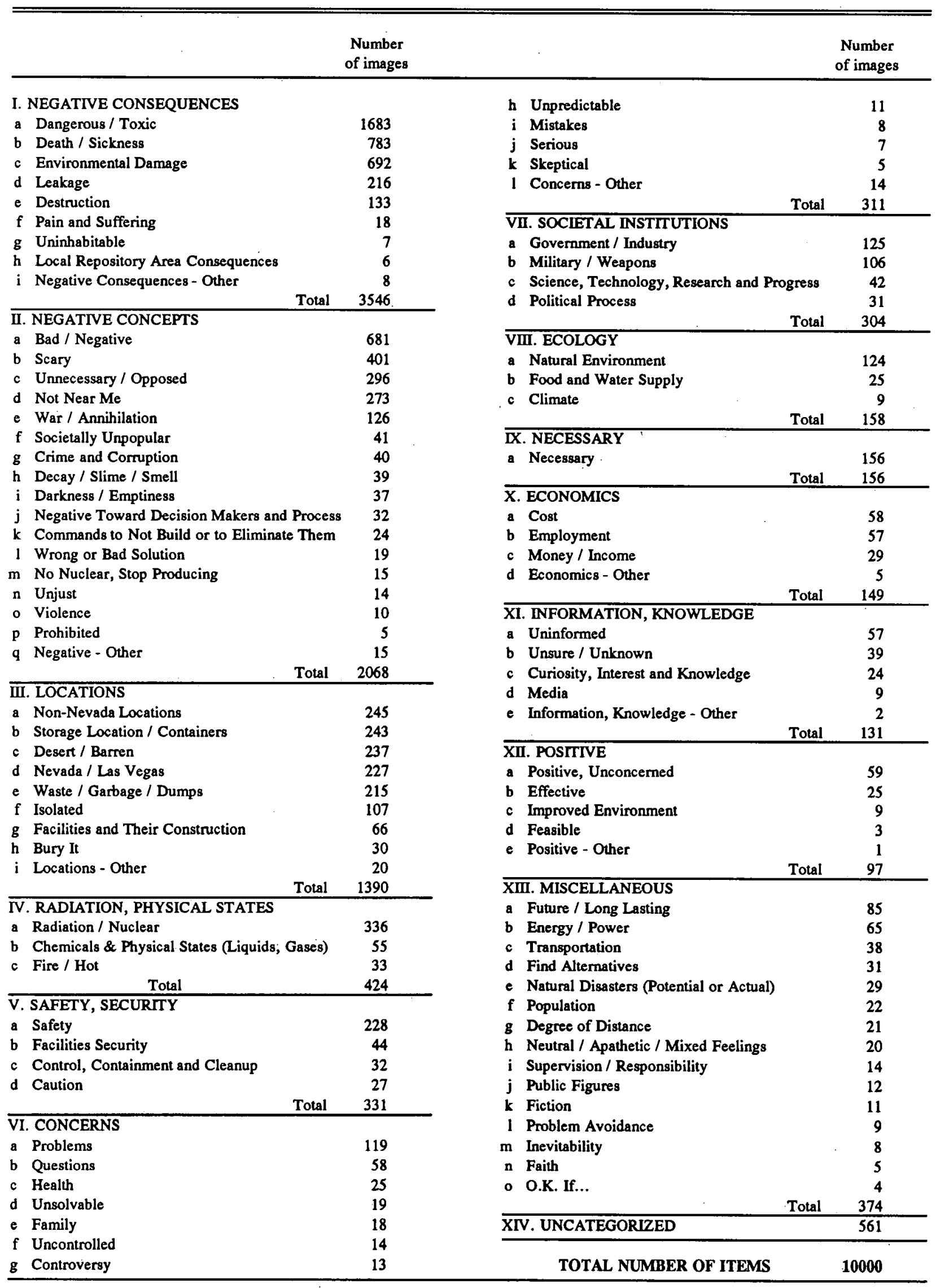


Perceived Risk, Trust, and Nuclear Waste Slovic, Layman, Flynn / Page 35

Table 7

Subordinate CATEgories ORdered by DECREASING FreQueNCy

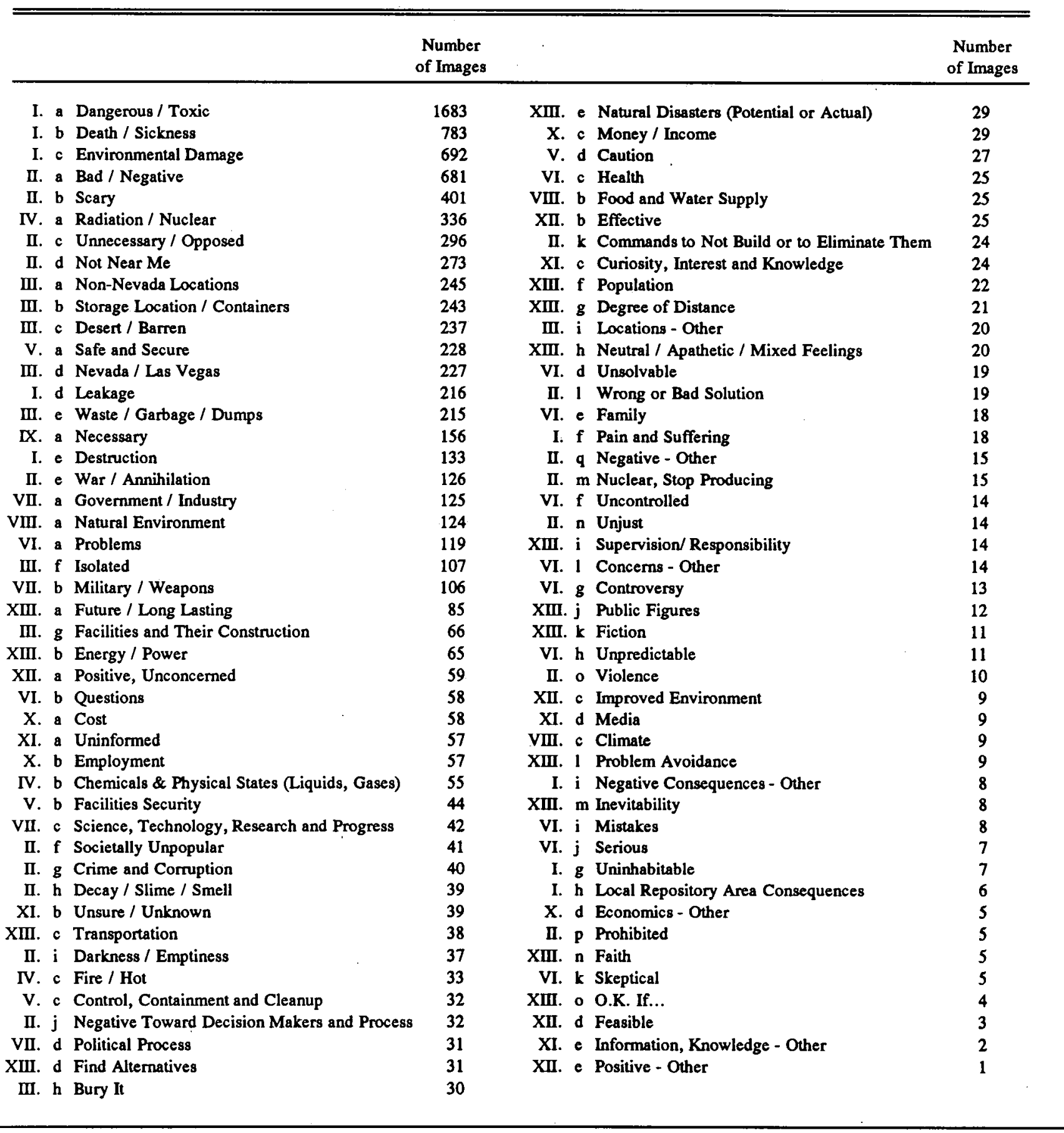

Note: Roman numerals indicate superordinate categories. 


\section{Table 8}

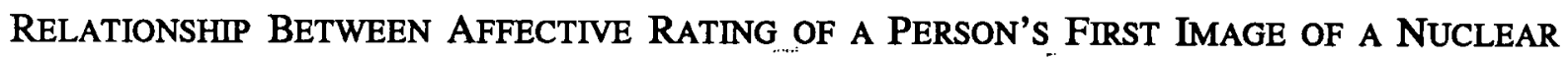
WASTE REPOSITORY AND THEIR RESPONSE TO THE QUESTION

"WOUld YOU VOTE For A REPOSITORY AT YuCCA MOUNTAIN?"

\begin{tabular}{cccccc}
\hline & \multicolumn{5}{c}{ Evaluation of the First Image } \\
\cline { 2 - 6 } Yucca Mountain Vote & $\begin{array}{c}\text { Very } \\
\text { Negative }\end{array}$ & $\begin{array}{c}\text { Somewhat } \\
\text { Negative }\end{array}$ & Neutral & $\begin{array}{c}\text { Somewhat } \\
\text { Positive }\end{array}$ & $\begin{array}{c}\text { Very } \\
\text { Positive }\end{array}$ \\
\hline Yes & 8.9 & 17.6 & 38.9 & 54.2 & 60.7 \\
No & 91.1 & 82.4 & 61.1 & 45.8 & 39.3 \\
N & 305 & 34 & 18 & 24 & 28 \\
\hline
\end{tabular}

Note: Cell entries are column percentages.

Responses based on a survey of Nevada residents.

$\chi^{2}=81.4 ; \mathrm{df}=4 ; \mathrm{p}<.001$ 
Perceived Risk, Trust, and Nuclear Waste Slovic, Layman, Flynn / Page 37

\section{Figure Caption}

Figure 1. Responses of Nevada residents when asked to rate their trust in federal, state, and local officials and federal agencies to do what is right with regard to a nuclear waste repository at Yucca Mountain. 
TRUST ON YUCCA MOUNTAIN State and Local Officials

Ratings for 1989 and 1991

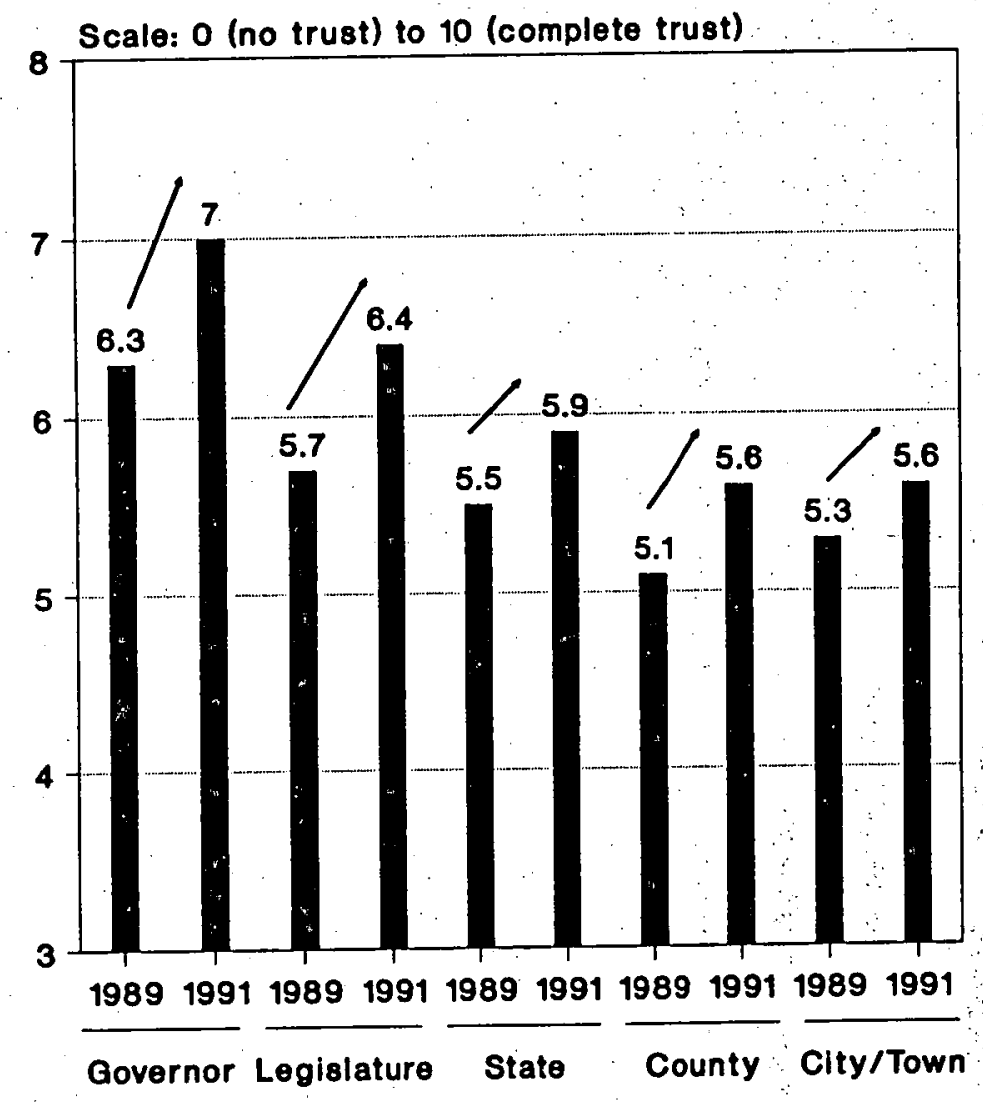

TRUST ON YUCCA MOUNTAIN Federal Officials and Agencies

Ratings for 1989 and 1991



